Supplement of Saf. Nucl. Waste Disposal, 1, 307-308, 2021

https://doi.org/10.5194/sand-1-307-2021-supplement

(C) Author(s) 2021. CC BY 4.0 License.

(c) (i)

Supplement of

\title{
Workshop - psychologically resilient communication between actors based on the example of a transdisciplinary approach
}

\section{Oliver Straeter and Pius Krütli}

Correspondence to: Oliver Straeter (straeter@uni-kassel.de) and Pius Krütli (pius.kruetli@usys.ethz.ch)

The copyright of individual parts of the supplement might differ from the article licence. 


\section{ETHzürich}

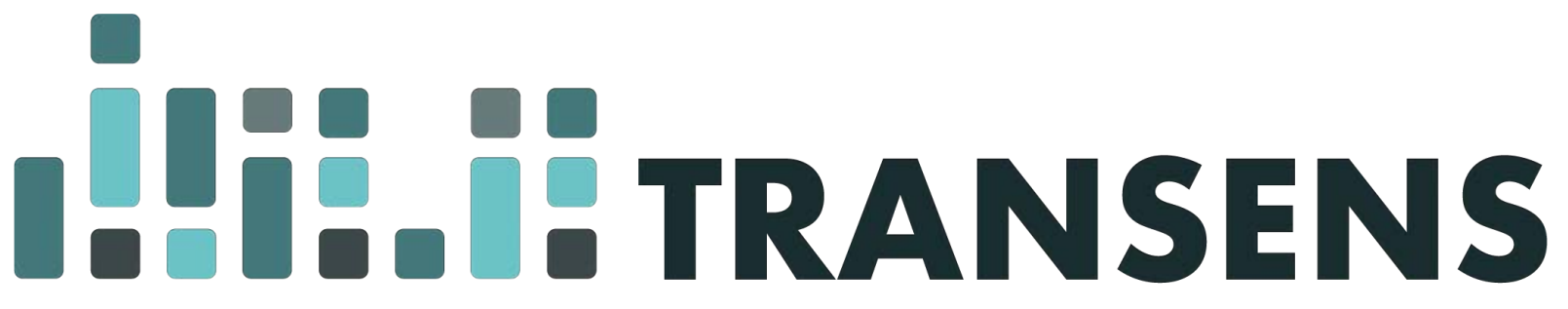

TRANSDISZIPLINÄRE FORSCHUNG ZUR ENTSORGUNG HOCHRADIOAKTIVER ABFÄLLE IN DEUTSCHLAND

Psychologically resilient communication in the interaction of actors using the example of the transdisciplinary approach - Workshop

BaseND Symposium, Berlin, 11th November 2021 Oliver Sträter, University of Kassel \& Pius Krütli, ETH Zurich 


\section{EHHzürich}

\section{Agenda (2h)}

09:40 Welcome, goals

09:45 Setting the scene

10:05 Input I

10:15 Exercise, group work (steps 1\&2)

10:35 Plenary discussion

10:50 Input II

11:00 Exercise, group work (steps 5,8,9)

11:20 Plenary discussions

11:35 Wrap up

11:40 End of Workshop 


\section{EHHzürich}

\section{Goal(s) of the workshop}

- Introduction to 10-steps approach for rendering research societally relevant

- Introduction to psychological aspects of communication

- Linking transdisciplinary research process \& psychology of communication

- Acquire some practical experience of these two tools 


\section{EHHzürich}

\section{Setting the scene - introductiory examples}

a) Example of a transdisciplinary research collaboration with the Swiss Federal Office of Public Health - support of decisions under pressure and uncertainty

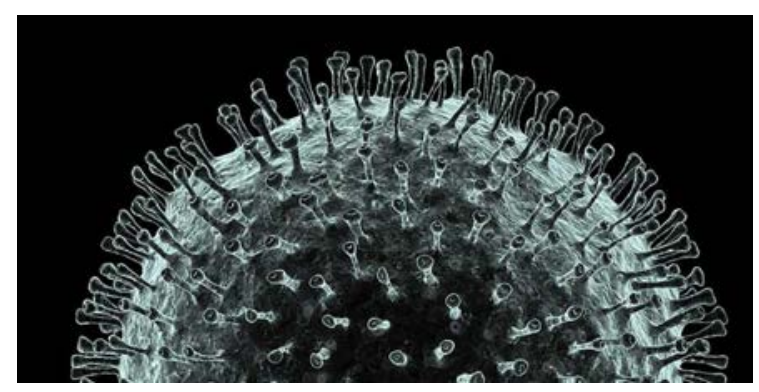

b) Why transdisciplinary research? Examples of relevance for safety

c) Feedback: Transdisciplinary issues in the current discussion of nuclear disposals 


\section{ETHzürich}

\section{(a) What is the project about; key characteristics}

- Modelling of effects of vaccination under the condition of scarcity - and epidemiological, regulatory \& societal requirements

- Joint ,problem farming' (co-design) and joint knowledge generation (coproduction

- Succession of interdisciplinary work (mathematics; informatics; epidemiology; social psychology; medicine) and continuous exchange

- Decision making support (decisions under high uncertainty)

- Moving target

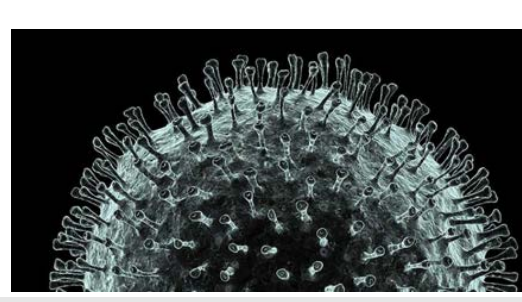




\section{ETHzürich}

\section{Some further characteristics}

- Continuous meetings (30 in 1y) to keep us on track

- Work under uncertainty and high time pressure

- Continuous learning process on both sides

- Modelling as learning tool

- Decision support vs decision making 


\section{ETHzürich}

\section{Findings}

- Communication is key

- Scientific evidence needs to be understood

- Participants are more than receivers of ,results' $\rightarrow$ bidirectional interaction on equal footing

- Listening is as important as talking

- Transparency (re: uncertainties, assumptions, etc.)

- Respect (e.g. other opinions)

$\rightarrow$ Trust building $\rightarrow$ creates ownership of the problem

$\rightarrow$ supports adoption of findings/learning

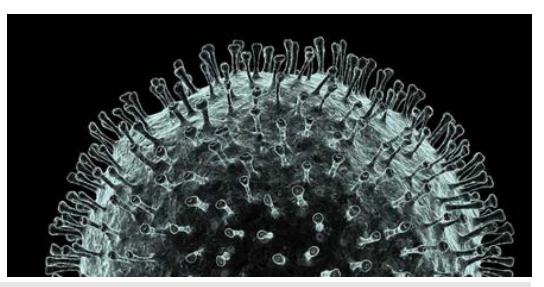


(b) Why transdisciplinary research? Examples of relevance for safety

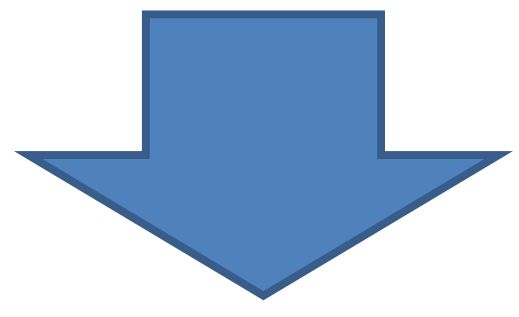

What is Listening, Transparency, Respect, Trust building and ownership of the problem good for? 


\section{ETHzürich}

(Some) Examples of lack in Listening, Transparency, Respect, Trust building and ownership of the problem

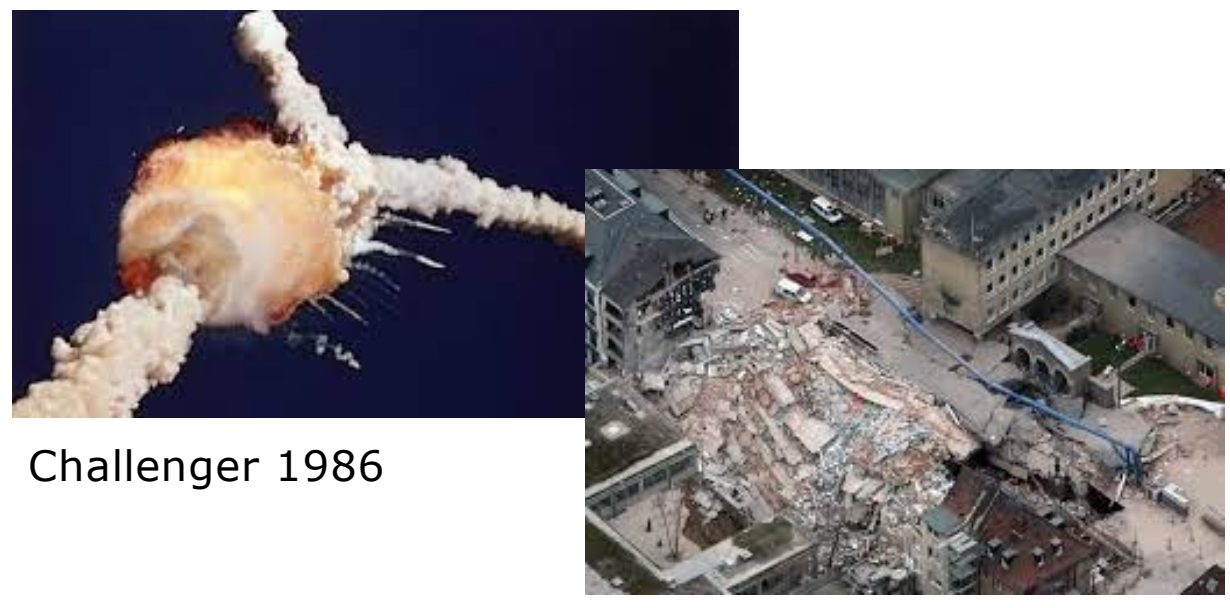

Cologne archive 2009
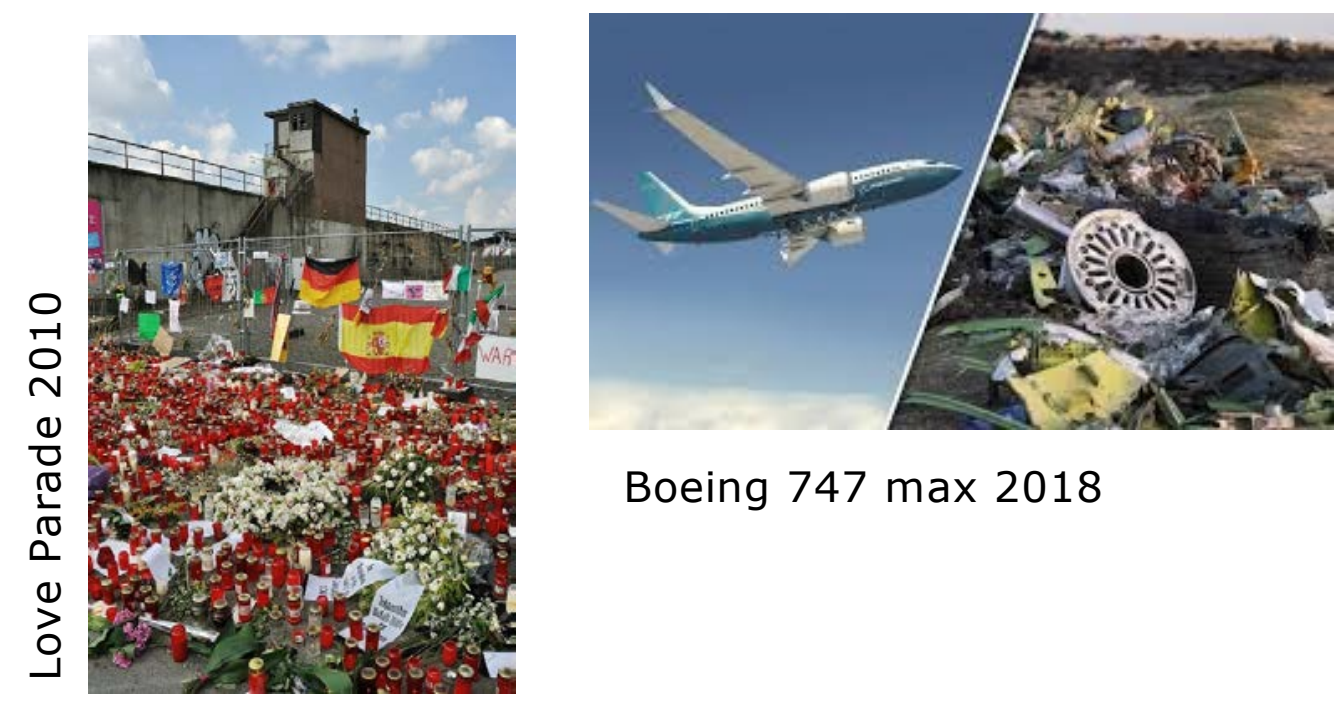

Boeing 747 max 2018

Severe accidents have a common psychological nature ... 


\section{EHHzürich}

Psychological Nature of Examples

- (Ab)Use of Power in decision making instead of mutual process

- Information hiding to seek for advantage

- Lack of considering minority-opinions Listening followed by loss of valid information

- Yielding Biases instead of thorough analysis leading to self-contradictions

- Omitting inclusion of other opinions, options or solutions

Psychological aspects overcome established safety-barriers.

Respect

Transparency

Trust building

Ownership of problem 
(c) Feedback: Transdisciplinary issues in the current discussion of nuclear disposals

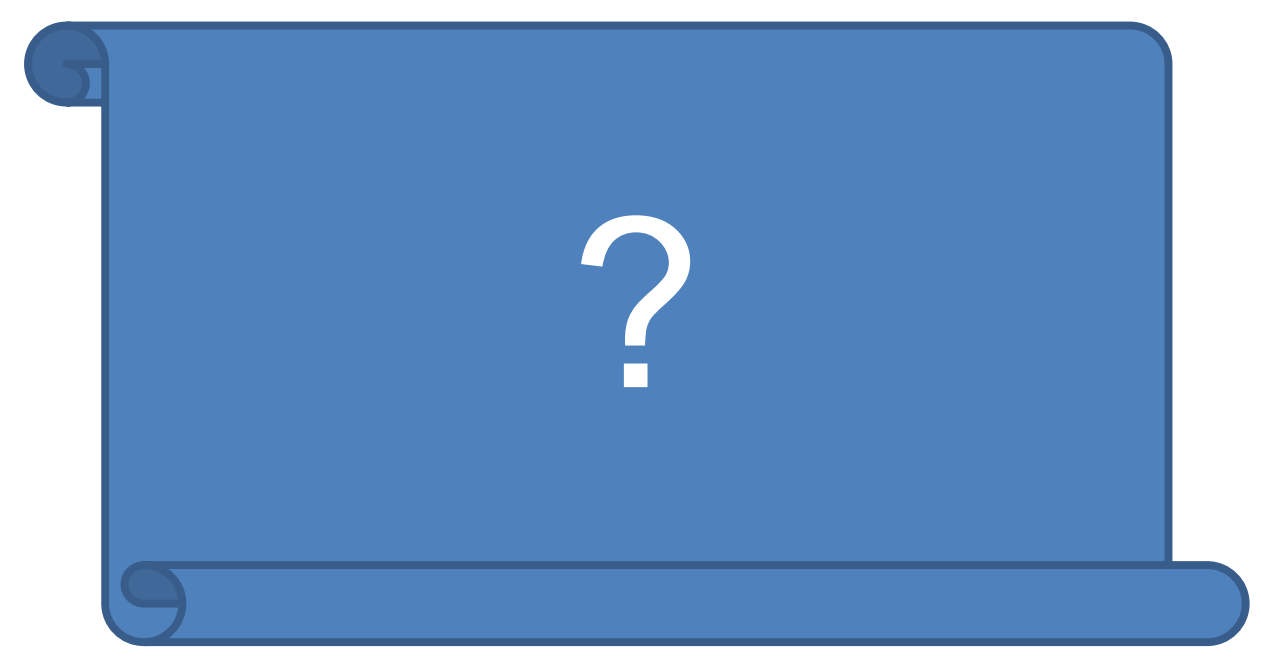




\section{EHHzürich}

U N I K A S S E L $V \quad E \quad R \quad S \quad I \quad T$ "A" T

$A \& O$

Input: 10 -steps, steps $1 \& 2$ 


\section{EHHzürich}

U N I K A S S E L

$\begin{array}{llllllll}V & E & R & S & I & T & \text { } A \text { " } & T\end{array}$

$A \& O$

\section{Ten reflective steps for rendering research societally relevant}
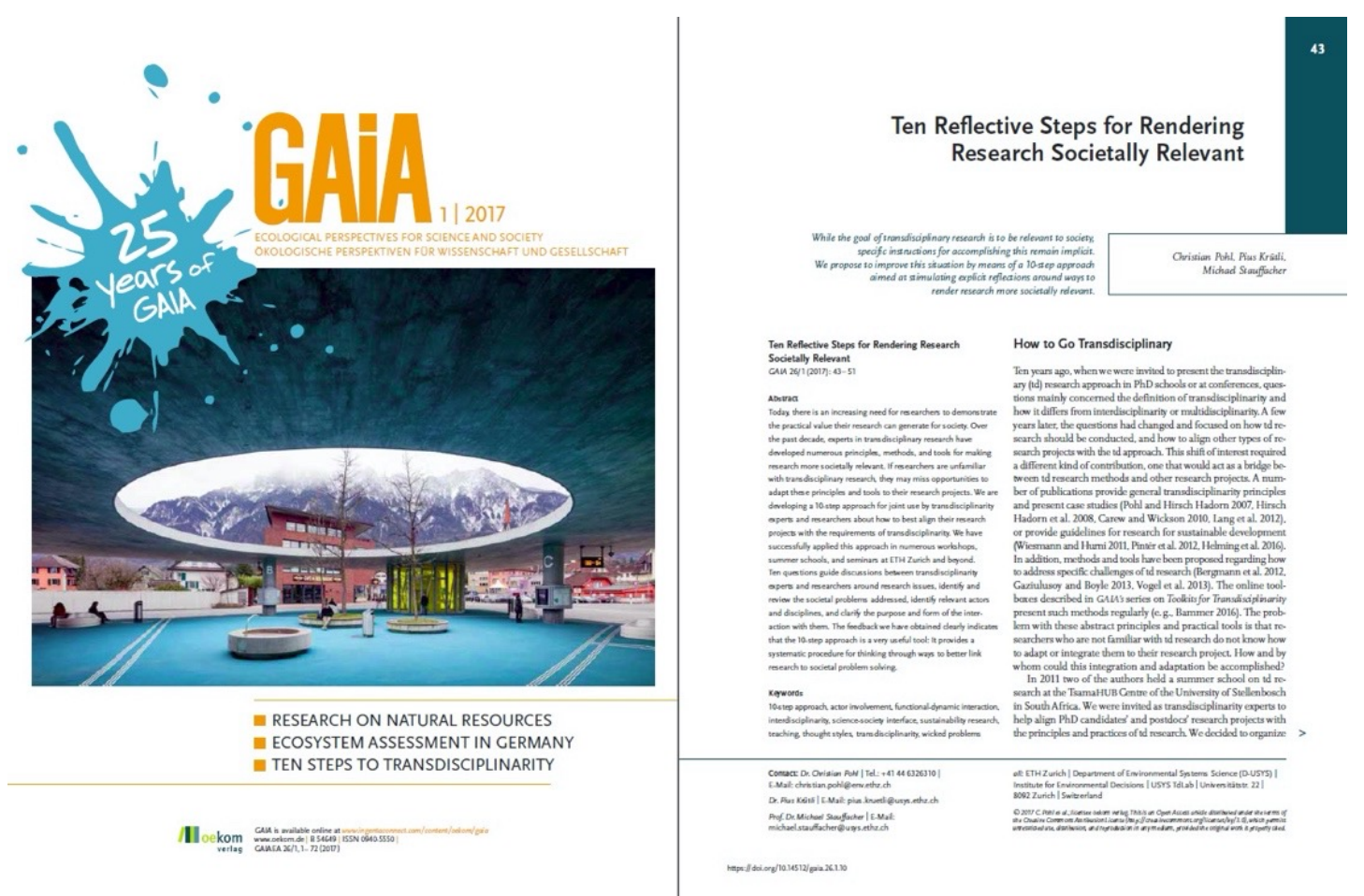


\section{EHHzürich}

\section{Goals of the ten steps}

- For td researchers: analyse own project and identify potentials for improving the science-practice interfaces

- For other researchers: analyse own project and reflect how own project is embedded in broader societal context

- For both: know how to use a set of questions for further iterative refinements after consultation of literature, (scientific) experts and stakeholders

- For ,practitioners': understand the logic of a transdisciplinary research process and learn how to contribute to a scientific project 


\section{EHHzürich}

\section{General structure of the ten steps}

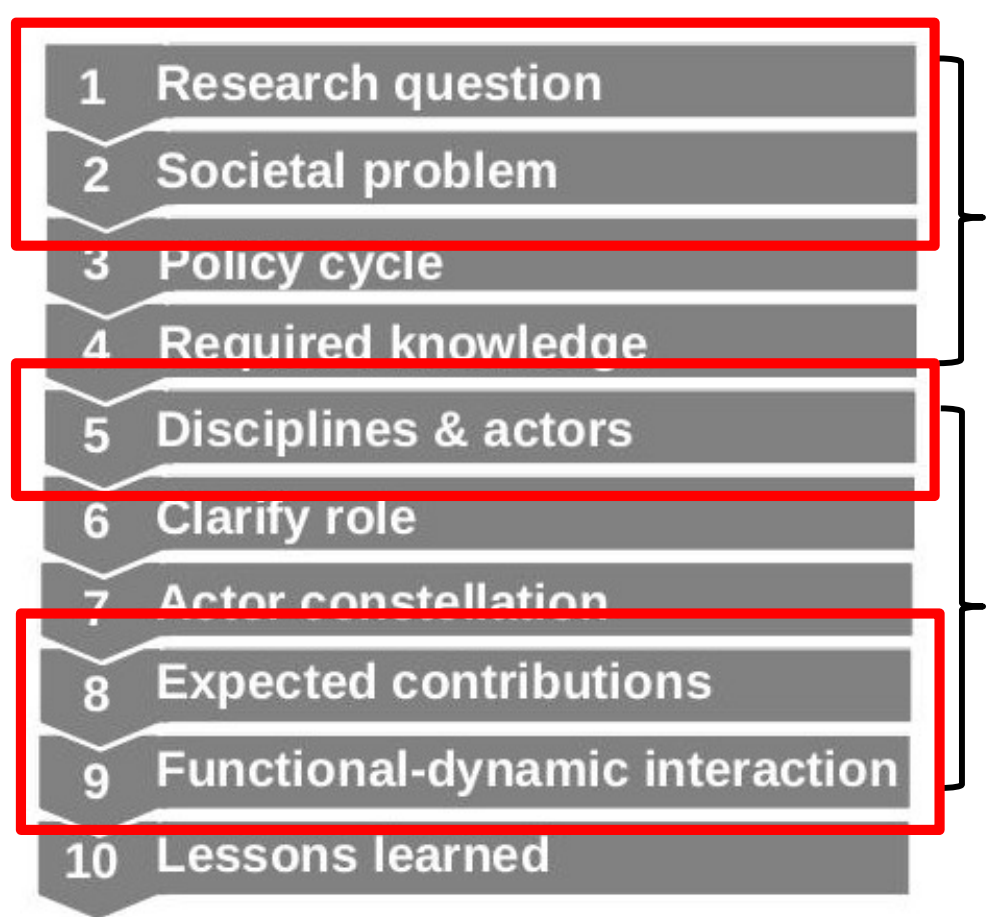

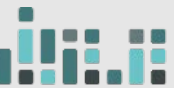

TRANSENS
- Steps 1 to 4 help you (re)framing your research project and how it relates to social problems $\rightarrow$ problem focus

- Steps 5 to 9 help you designing interactions with other disciplines and social actors

$\rightarrow$ people focus

- Important: it is an iterative process, steps 5 to 9 might indicate that you need reframing your research (again) 


\section{Step 1: Formulate your research question(s)}

Formulate a research question and classify research as basic, applied, or transdisciplinary.
This step helps the researchers to recognize that there are two different realms, and that positioning one's own research between them might cause tension. 


\section{EHHzürich}

U N I K A S S E L V E R S I T "A" T

$A \& O$

Research questions can be at different places of the science-practice interface

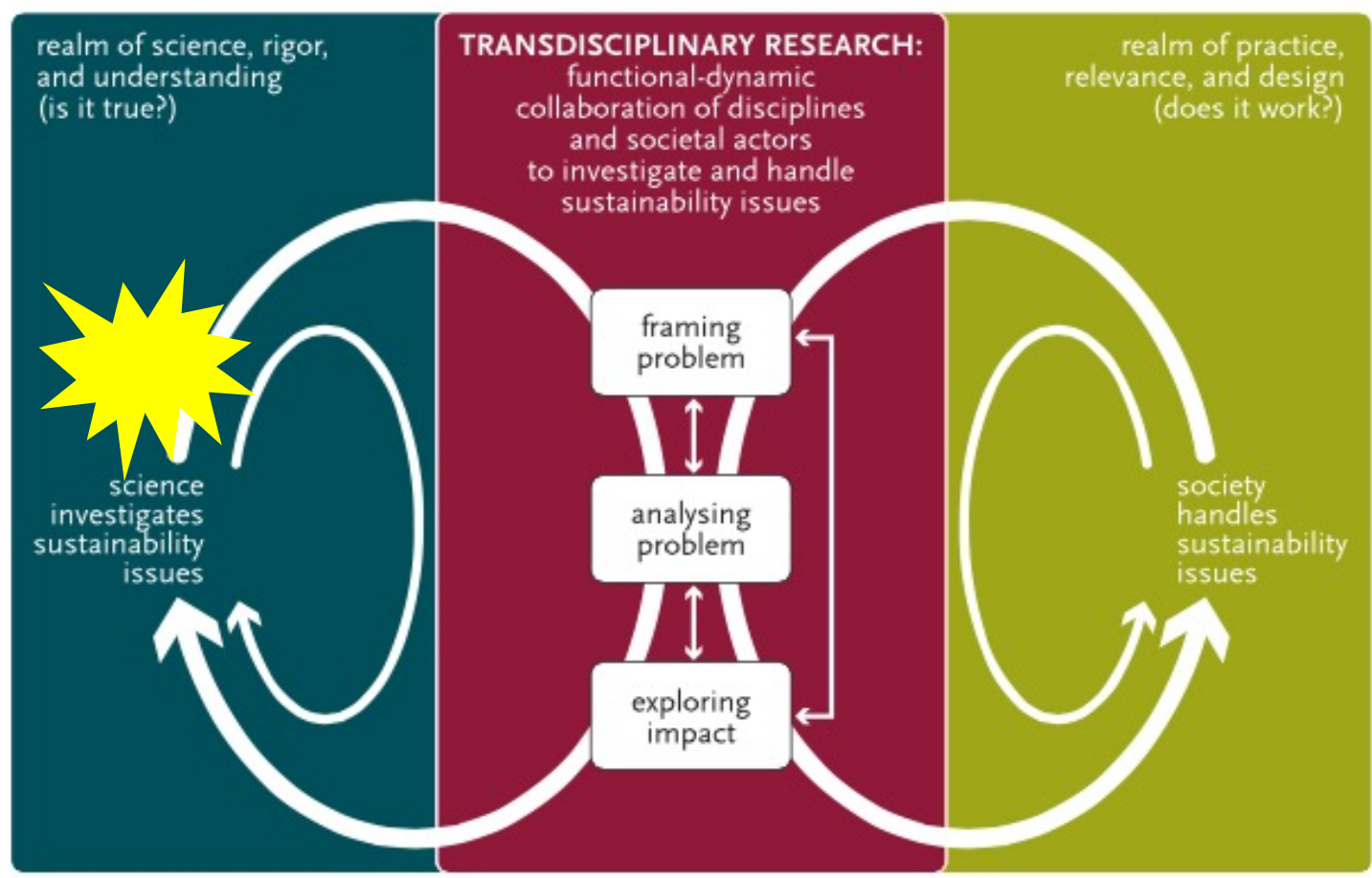

ili:.:

TRANSENS
(Pohl, Krütli and Stauffacher 2017) 


\section{EHHzürich}

\section{Problem framing in basic research}

A \&

$\begin{array}{ll}\text { Disciplines } & \begin{array}{l}\text { Problem fields } \\ \text { practices }\end{array} \\ \text { molecular biology } & \text { poverty } \\ \text { ecthics } & \begin{array}{l}\text { business } \\ \text { civil society }\end{array} \\ \text { ecology } & \begin{array}{l}\text { diseases } \\ \text { public } \\ \text { agencies }\end{array}\end{array}$

Problem/Problemsolving: describing and explaining processes by general models

Fig. 1-Identifying and structuring problems in basic research.

(Pohl and Hirsch Hadorn 2007) 


\section{EHHzürich}

U N I K A S S E L V E R S I T "A" T

$A \& O$ Research questions can be at different places of the science-practice interface

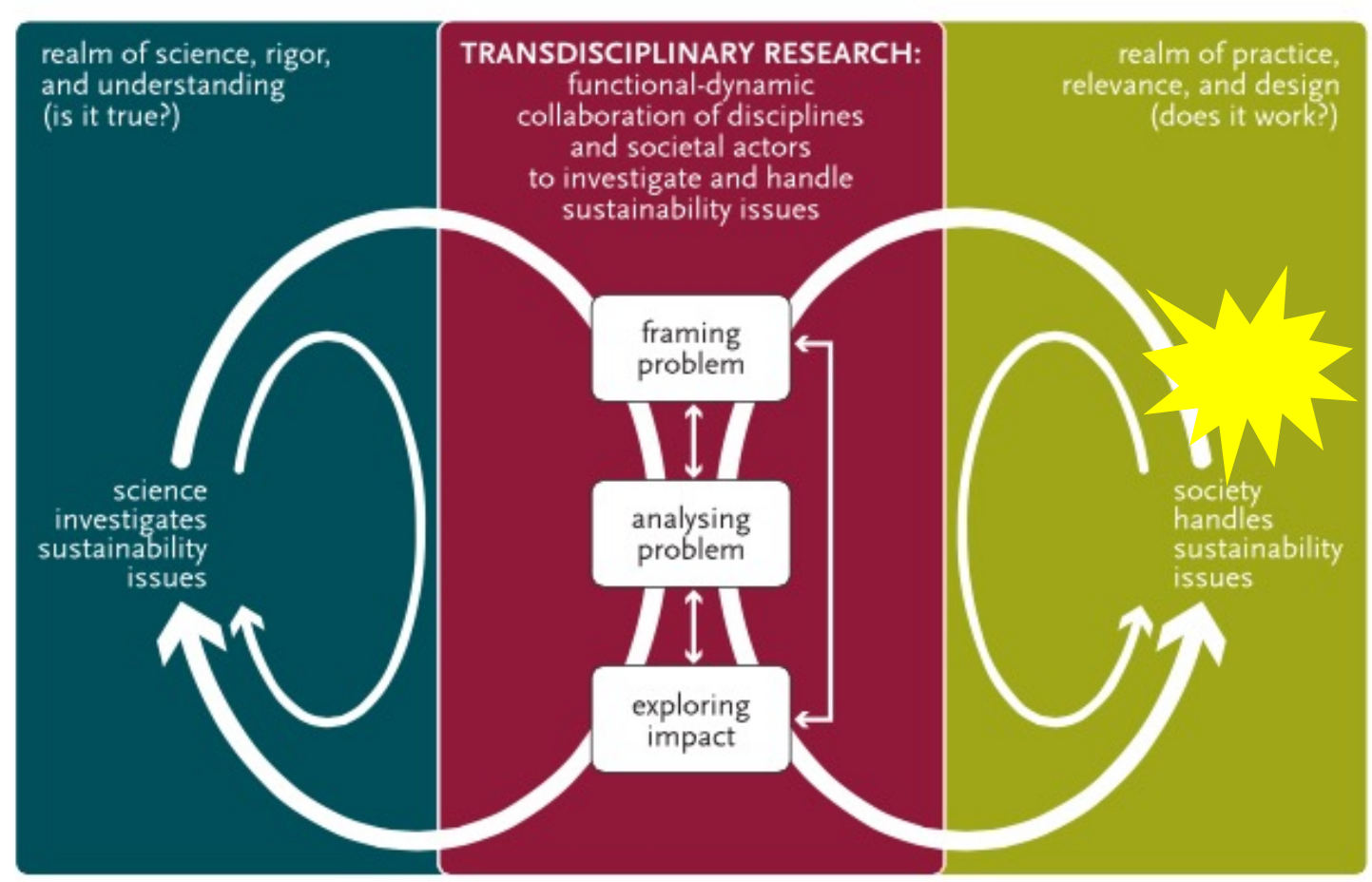




\section{Problem framing in applied research}

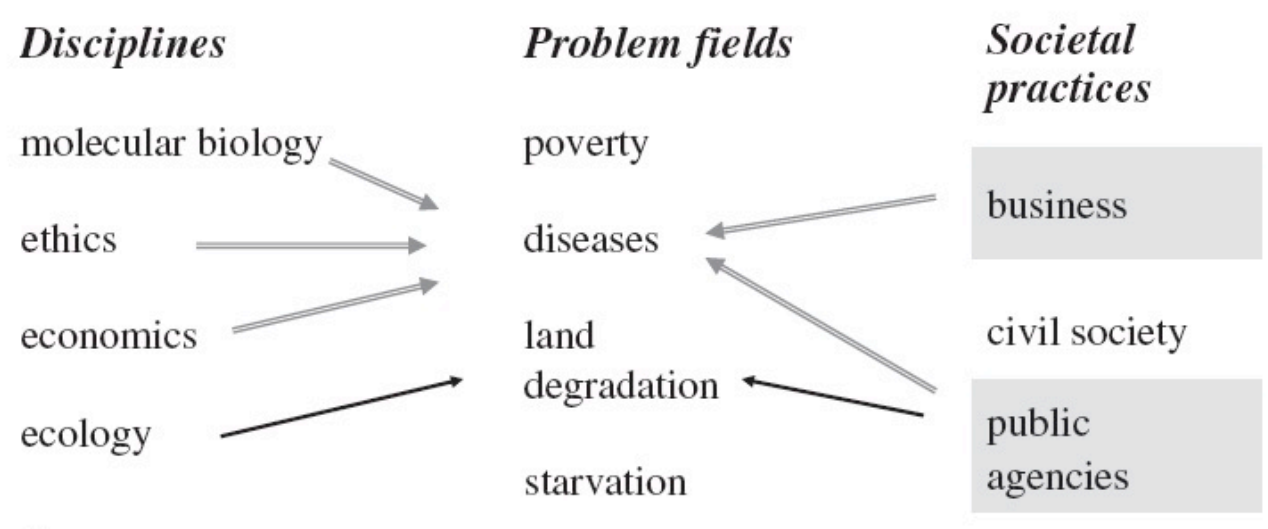

Problem/Problemsolving: describing and explaining the variability of processes in a problem field and developing measures to improve practices of clients

Fig. 2-Identifying and structuring problems in applied research. 


\section{EHHzürich}

U N I K A S S E L V E R S I T "A" T

$A \& O$ Research questions can be at different places of the science-practice interface

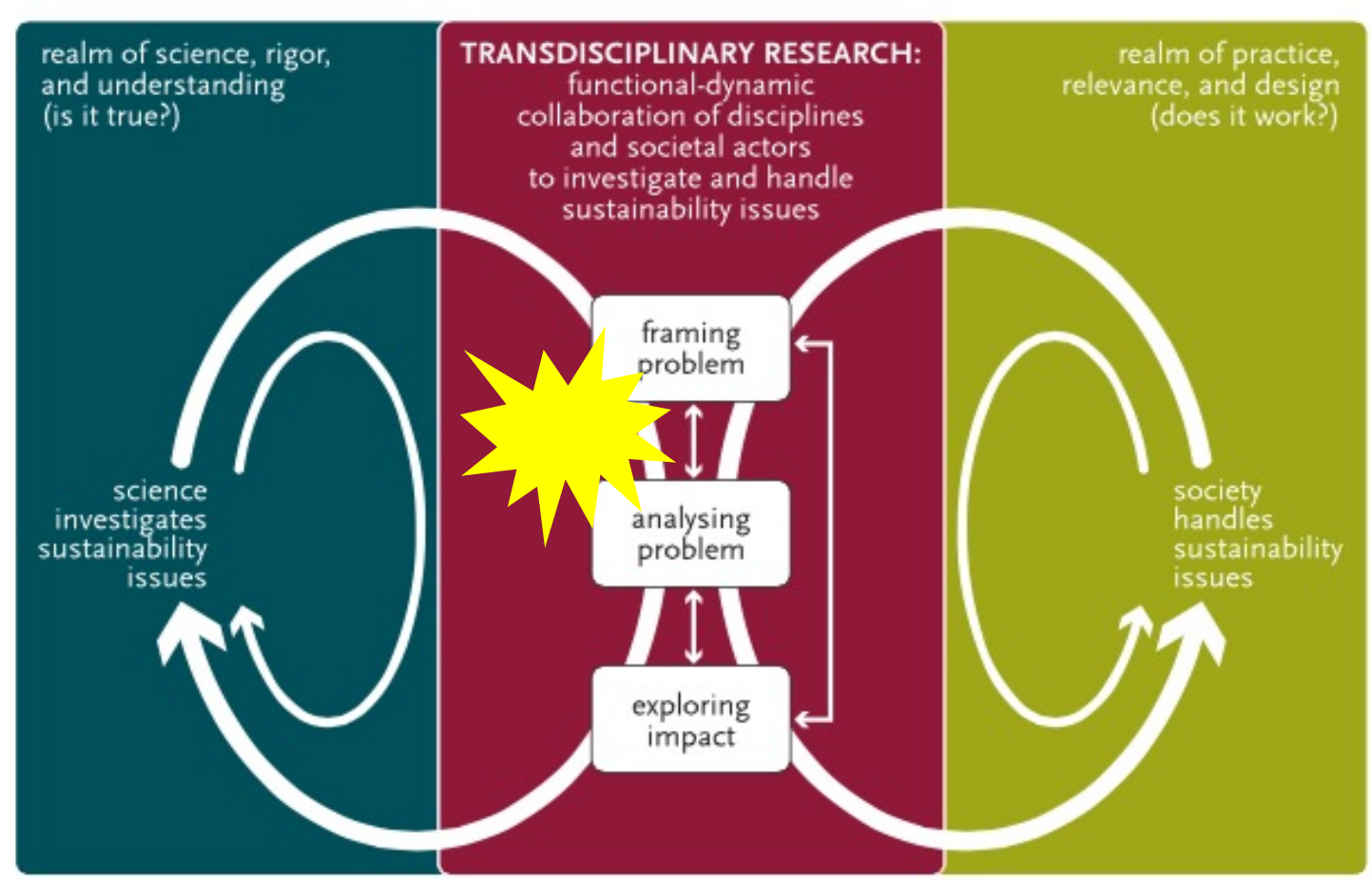




\section{EHHzürich}

\section{Problem framing in transdisciplinary research}

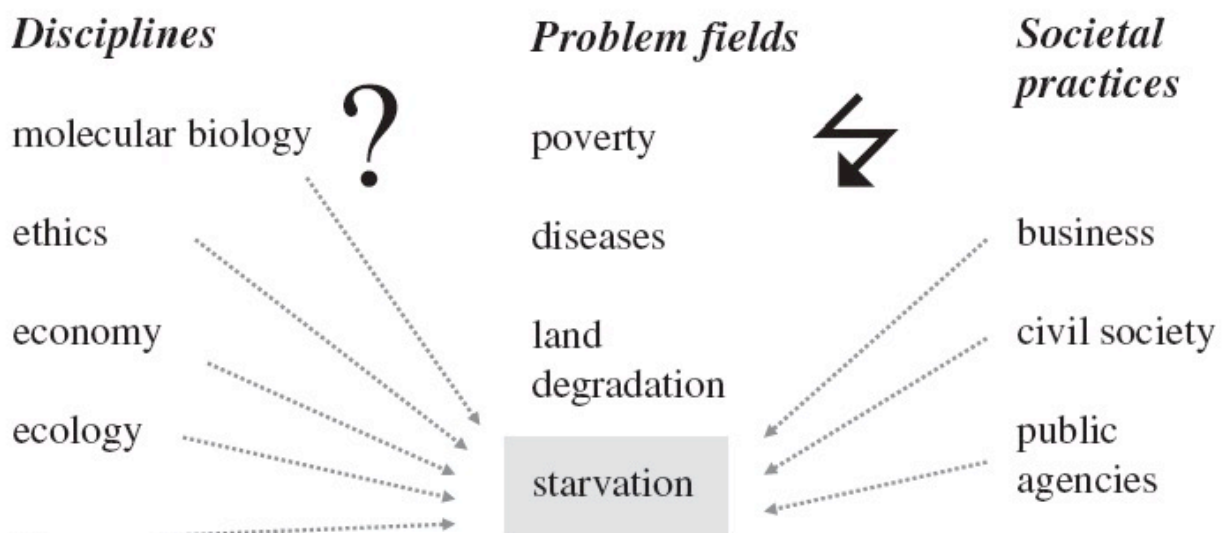

Problem/Problemsolving: understanding the complexity of issues and considering related practices with regard to the common good and the precautionary principle

Fig. 3-Identifying and structuring problems in transdiciplinary research. 


\section{ETHzürich}

U N I K A S S E L

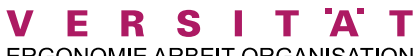

A $\&$ O

\section{Step 2: Formulate the societal problem you want to help solve}

Distinguish between research question and societal problem; make links between both.
This step makes the researchers reflect about what the societal problem actually

is, and if and how their own research contributes to solving a societal problem. 


\section{EHHzürich}

U N I K A S S E L

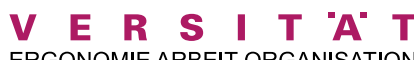

$A \& O$

\section{What societal problem does your project help to} solve? Through which steps?

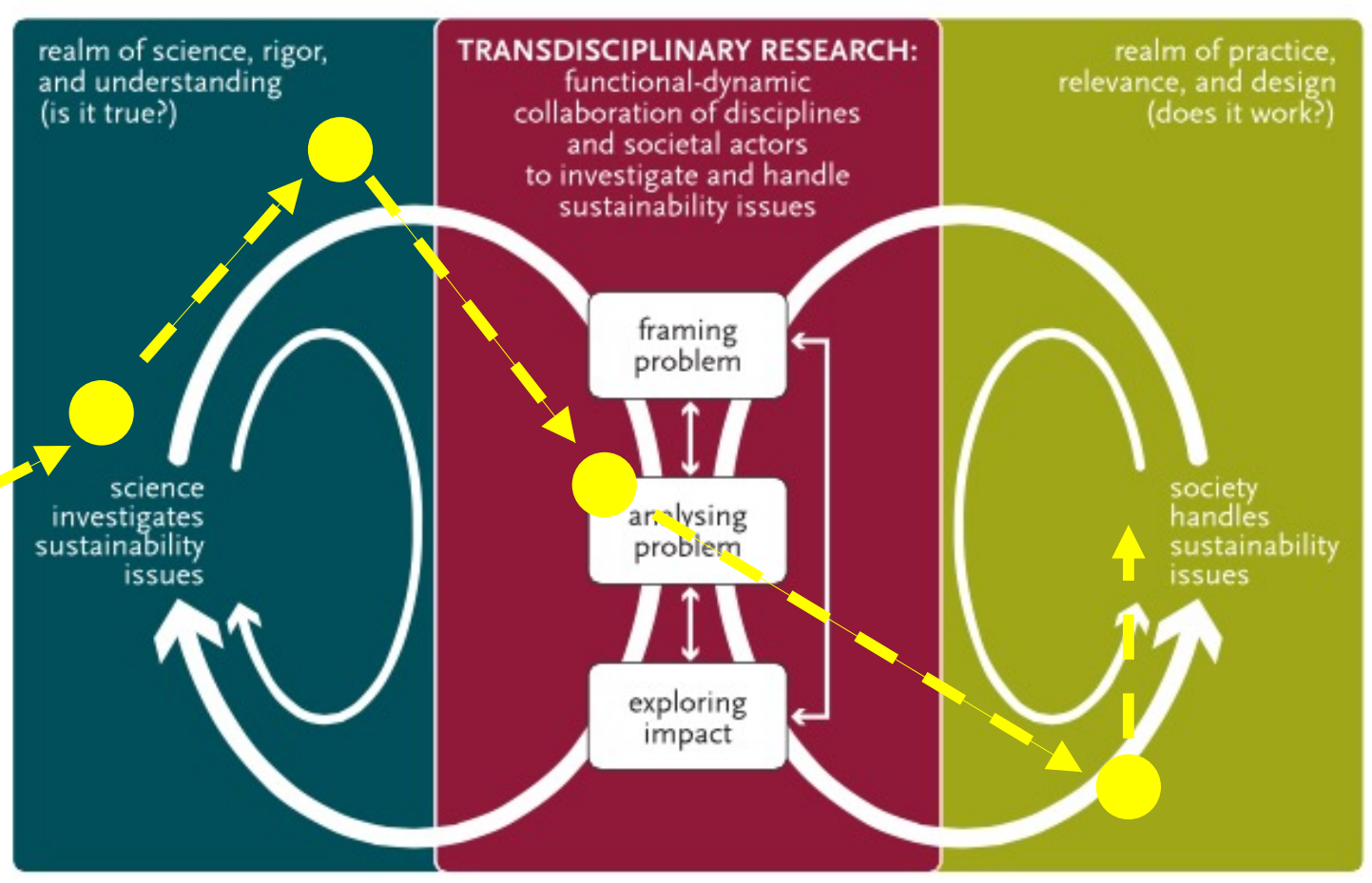




\section{EHHzürich}

\section{Exercise 1}

Topic Site selection process for a deep geological repository for high level nuclear waste

Task (1) Think about a potential field (a) of interest to be researched, and (b) that is societally relevant

(2) Formulate a research question (RQ) (can be a social sc. or a science/engineering oriented RQ or a combination of both)

(3) What is the related societal problem you want to help soling

Alternatively, you can start with 3 and then go to 2

Format Group work (mixed groups of scientists and ,practitioners')

Time 20' 


\section{EHHzürich}

U N I K A S S E L

$\begin{array}{llllllll}V & E & R & S & I & T & A & T\end{array}$

$A \& O$

\section{The role of communication}

\section{Communication is ...}

- 1st emotional

... and only ...

- 2nd content

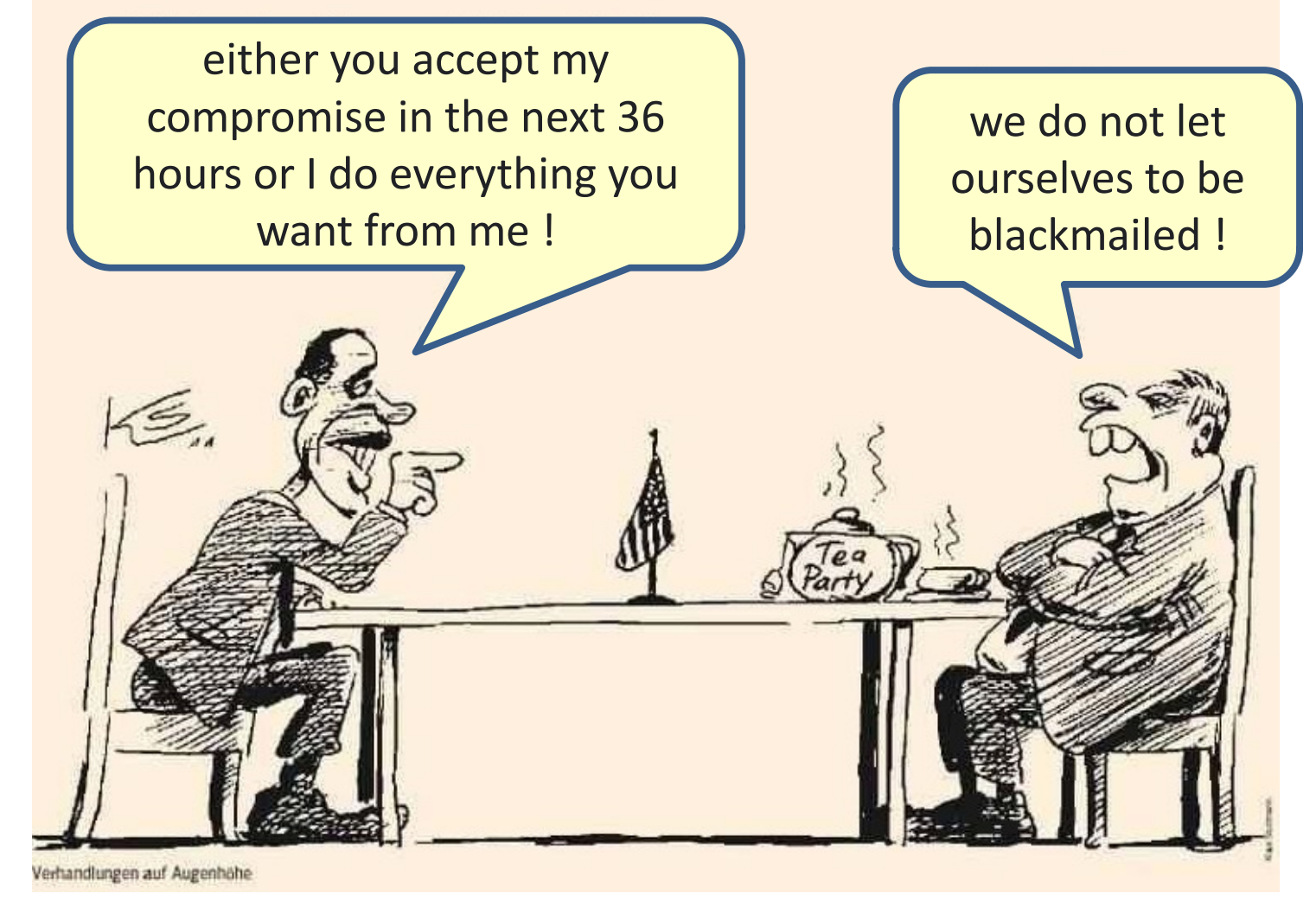




\section{ETHzürich}

\section{The hard wired structure of communication}

\section{Emotional regulation ...}

- ... protects own experiences

- ... defends endangering interventions

- ... tends to diminish / fight endangering actors

usually results into negative feedback loops

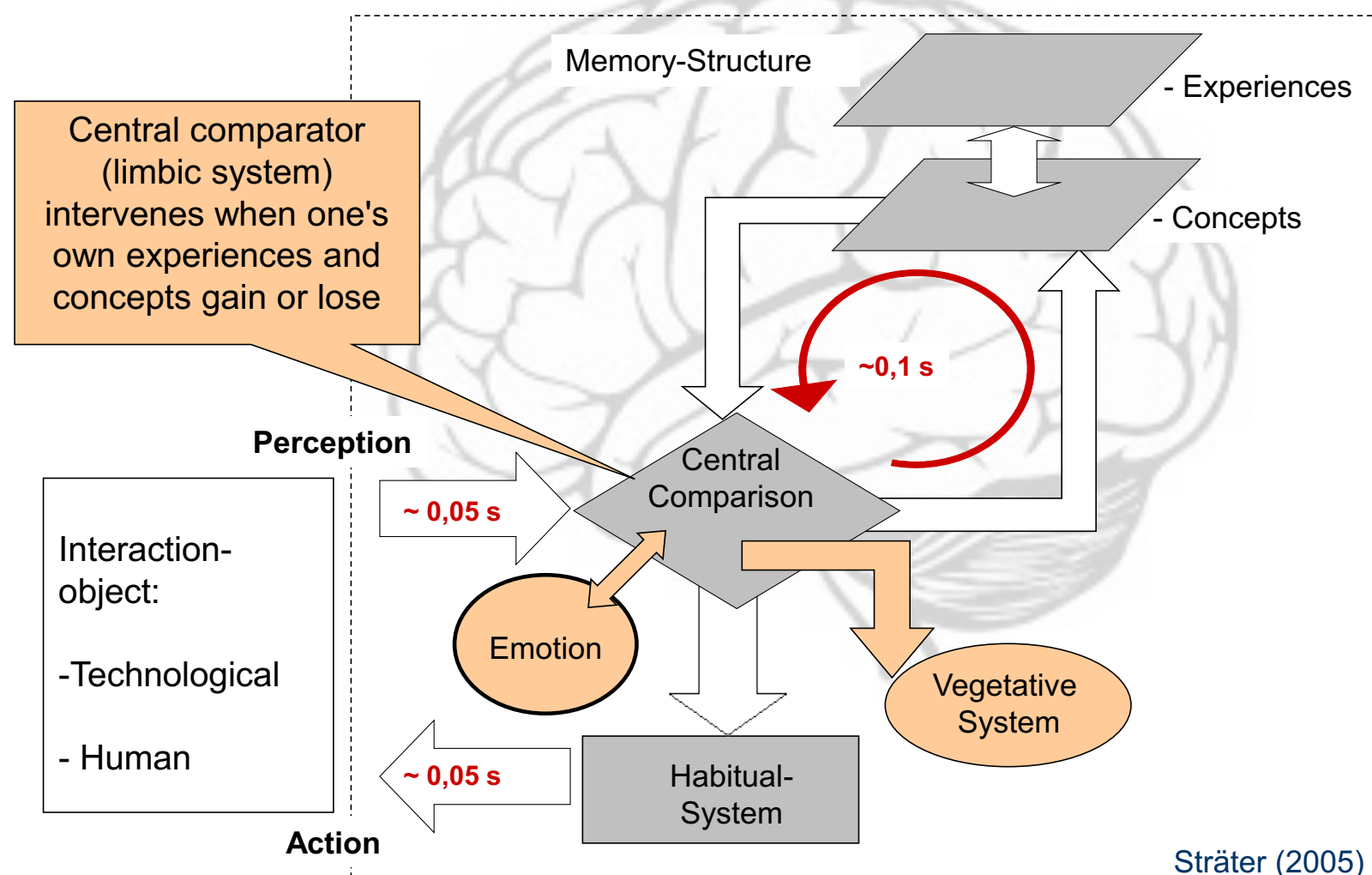

Oliver Sträter \& Pius Krütli BaseND- 10 steps/communication WS 


\section{EHHzürich}

U N I K A S S E L

Overcoming the emotional barrier ...

... within myself

Think positive on disagreements

Accept emotion as hint for issue

... of the other cognitive

emotional

Accept anger as hint for experience Appreciate level of emotion as importance habitual

Do not reply with anger

Interpret emotions as seek for interaction

Working with emotions rather than let them work you ... 


\section{EHHzürich}

\section{GROW Model of Communication}

\section{Healthy appreciation \& positive feedback}

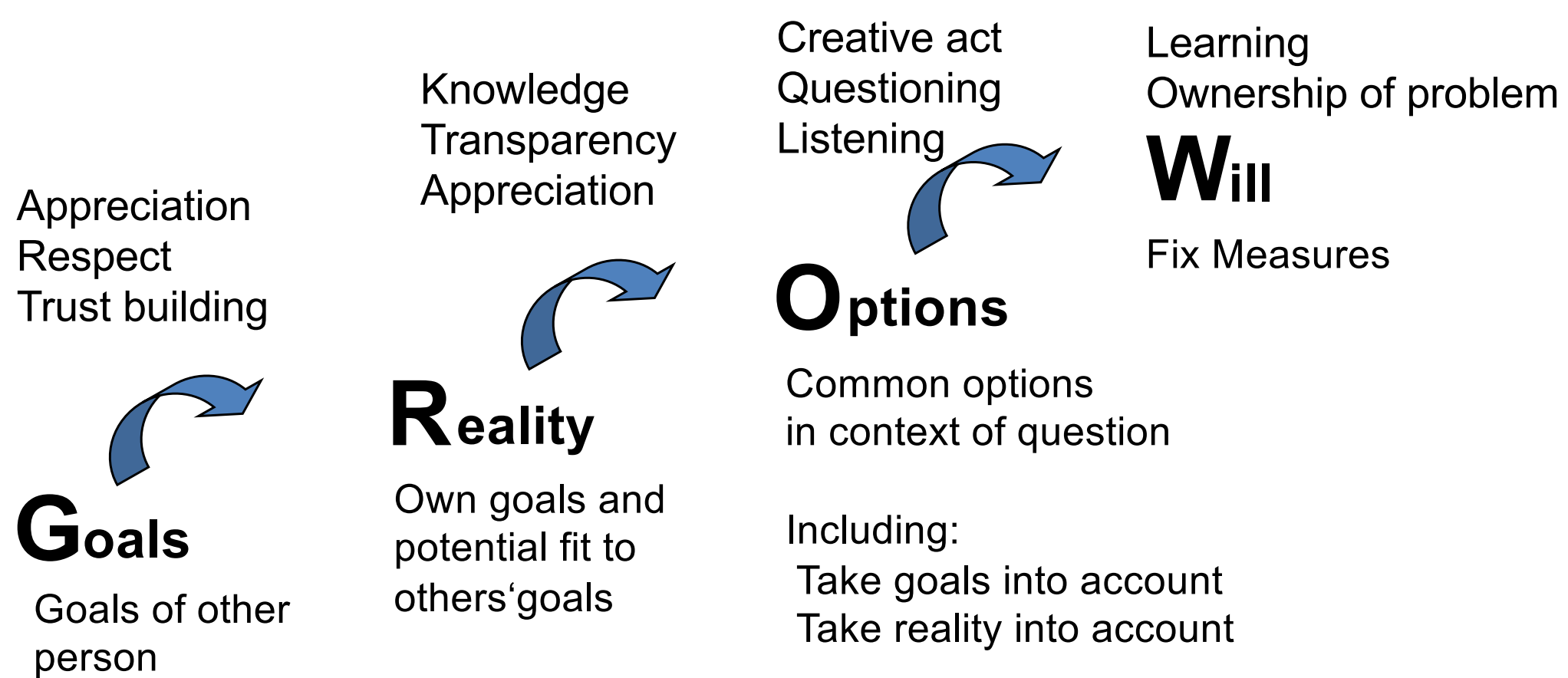




\section{ETHzürich}

For the Exercise

... always start conversation with the position of the other

... force yourself seeing the world from the position of the other (positively)

... if a statement makes you angry, start appreciating this as opportunity for own progress

... get your position in as second and on the same power-level (neither higher, nor lower)

... try to find creative solutions for all positions (others and you)

\section{Working with emotions rather than let them work you ...}




\section{EHHzürich}

U N I K A S S E L $V \quad E \quad R \quad S \quad I \quad T$ "A" T

$A \& O$

\section{Input: 10-steps, steps 5, 8, 9}




\section{ETHzürich}

U N I K A S S E L

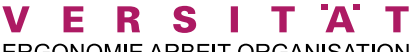

A \& $\mathrm{O}$

\section{Step 5: Identify relevant disciplines and societal} actors

Identify disciplines and societal actors to be involved in the research project.
This step specifies and extends steps 3 and 4 to the world of societal actors and disciplinary researchers. It increases awareness of relevant expertise and decision power available elsewhere. 
ETHzürich

Disciplines and societal actors might be relevant because of their...

... interest

... power

... expertise 


\section{ETHzürich}

\section{Step 8: Clarify Disciplines' and Societal Actors' expected contributions}

Clarify expectations and interests of the societal actors and disciplines involved.
Researchers must substantiate why societal actors and other disciplines need to be involved. This makes the vague notions of involvement and interaction

(see steps 5,6) more explicit and concrete. 


\section{EHHzürich}

\section{Three rationales of involvement}

Fiorino (1990) distinguished between three reasons for public participation

- substantive (i. e., those to be involved have relevant expertise),

- normative (i. e., the democratic principle requires that those affected have a say),

- instrumental (i. e., by interaction one hopes for more legitimized decisions). 


\section{Forms of interactions}

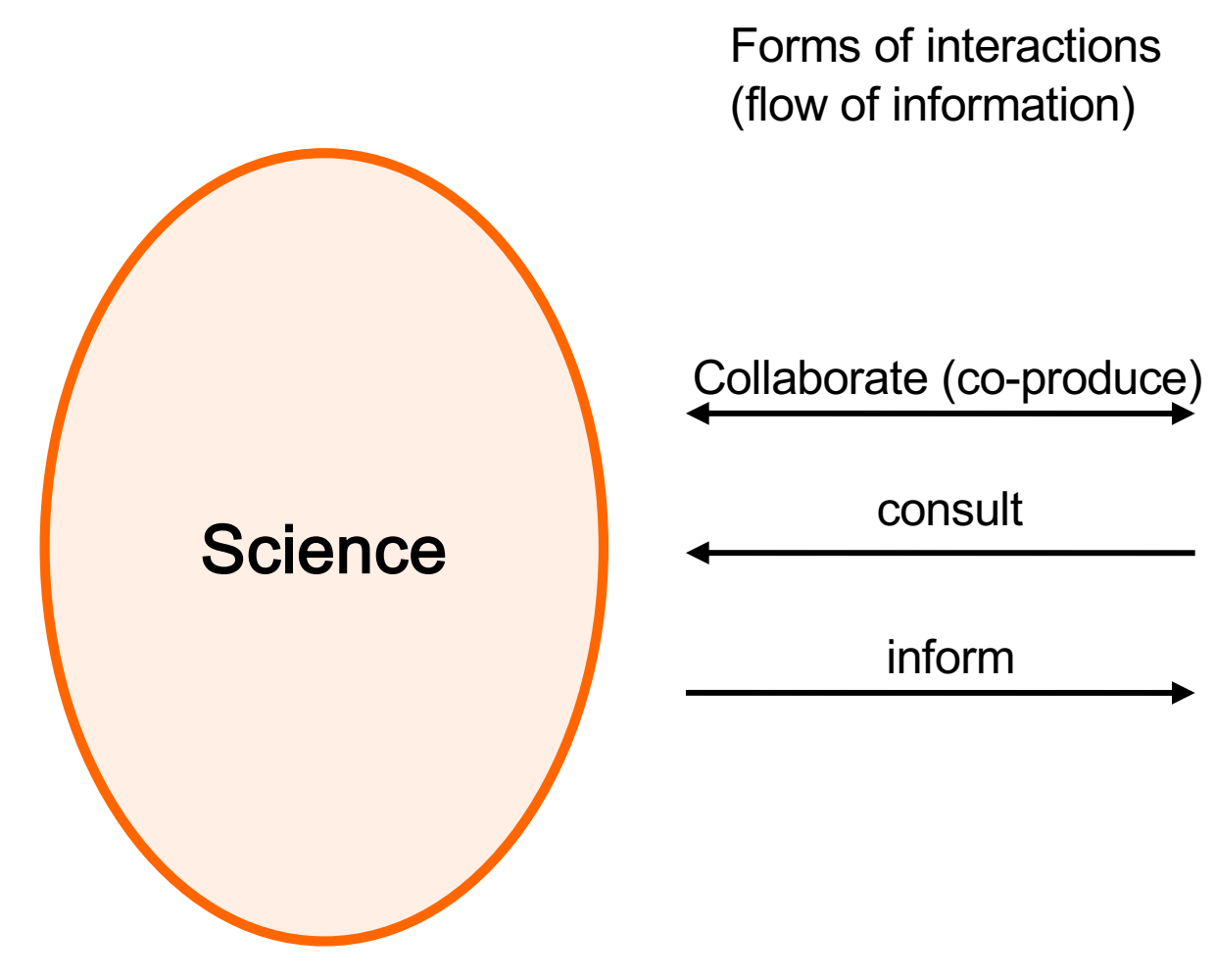

Forms of interactions

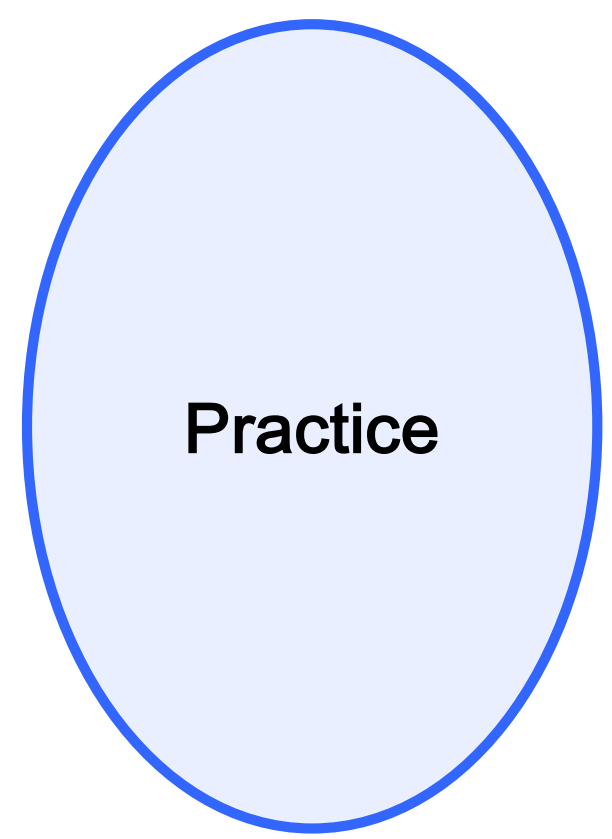

(Rowe \& Frewer 2005; Jahn et al. 2012) 


\section{Step 9: Plan a functional-dynamic interaction}

A \&

\& $\mathrm{O}$

Design a plan on why to involve which societal actors and disciplines at different stages of the research project.
This step encourages reflections about who to involve/collaborate within one's research project depending on the desired societal impacts. It helps to understand that collaboration is dynamic over time. 


\section{EHHzürich}

\section{Td-research: Actor involvement - why, who, when, and how}

Public participation: Key questions pattern

Td-research

Process owner's perspective (who involves)

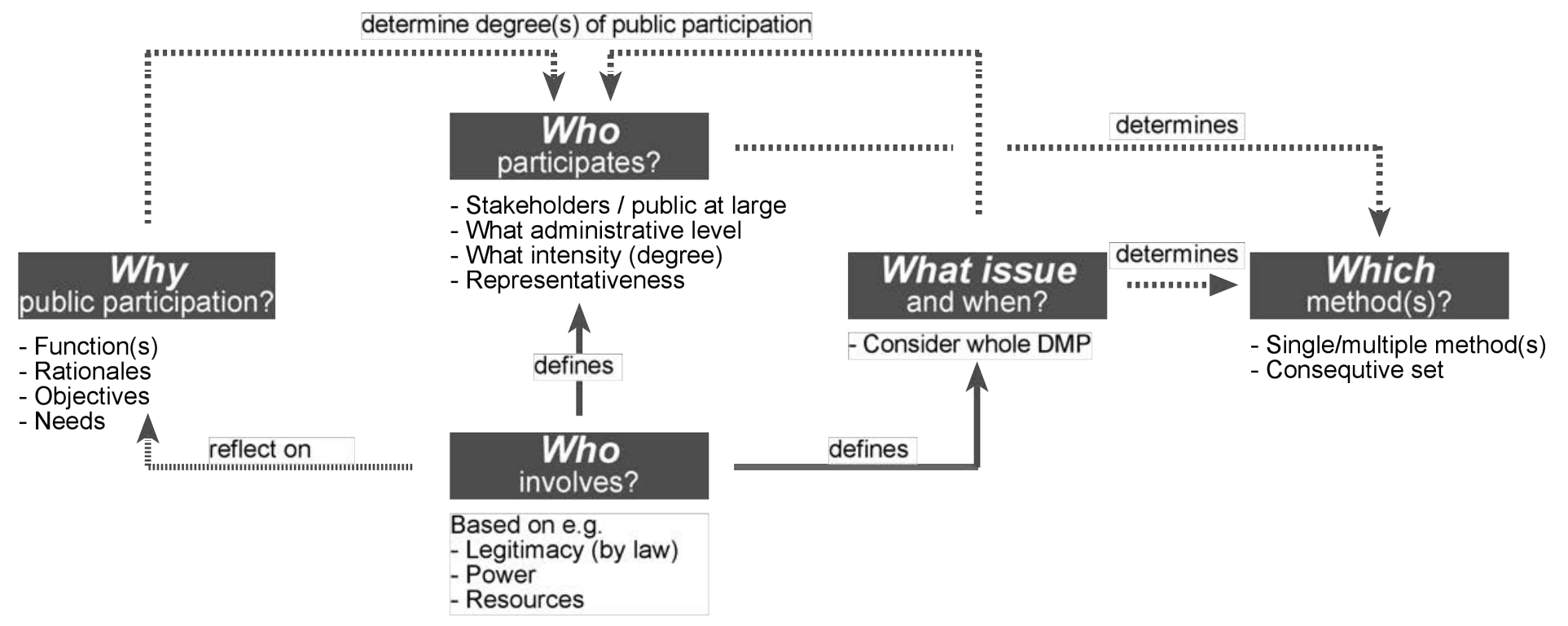


ETHzürich

\section{Who to involve, when and how?}

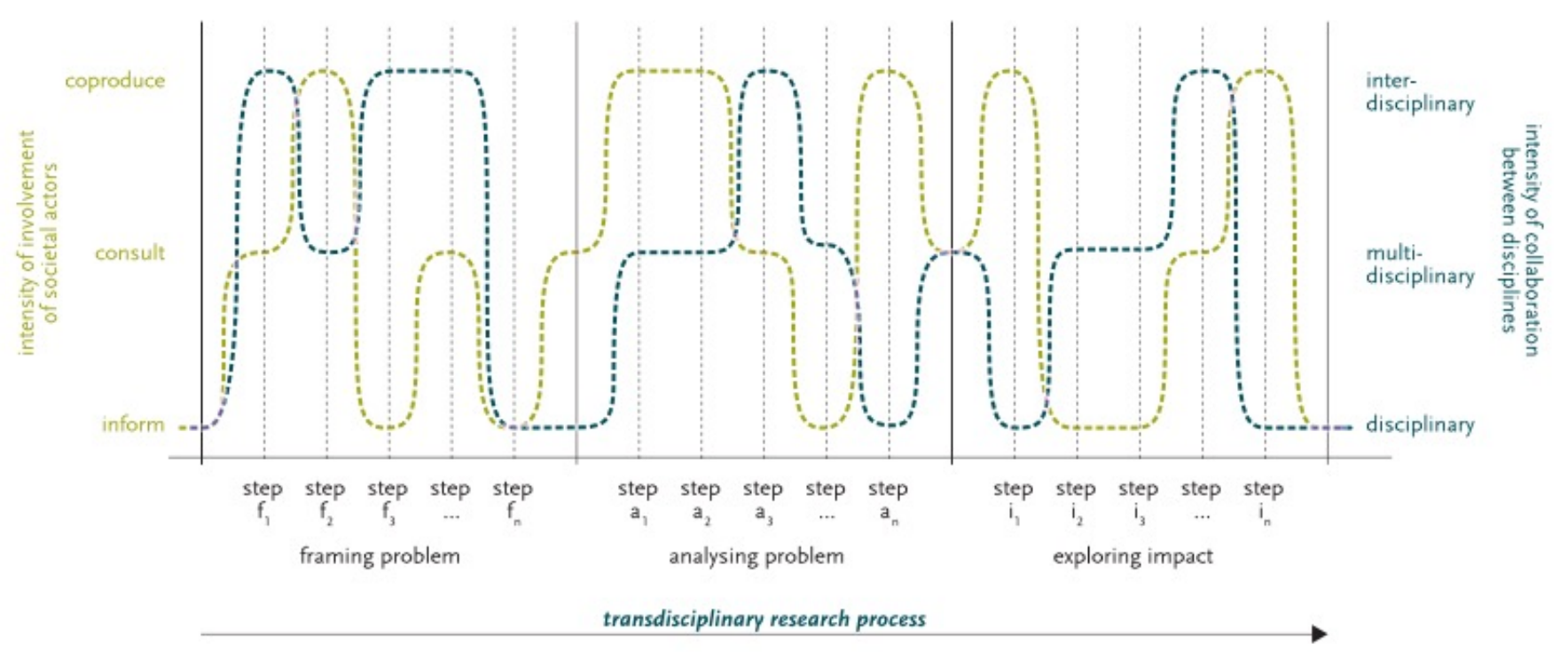

FICURE 4: Functional-dynamic approach to collaboration in a hypothetical project. The intensity of involvement of societal actors (light green dotted line) and of the collaboration between disciplines (dark green dotted line) varies over the transdisciplinary research process. It depends on the stage, goals, and content of the process as well as its context (further developed based on Stauffacher et al. 2008 and Krütli et al. 2010).
U N I K A S S E L

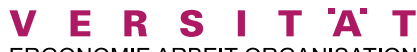

$\mathrm{A} \& \mathrm{O}$ 


\section{EHHzürich}

\section{Exercise 2}

Topic Site selection process for a deep geological repository for high level nuclear waste

Task (1) take your research question and your societal problem you want to help solving

(2) Think about (a) which discipline(s) should contribute to,

(b) which societal actor(s) should be involved, and (c) why

Format Work in the same group work as before

Time 20' 


\section{EHHzürich}

\section{References}

- Fiorino, D. J. (1990). Citizen Participation and Environmental Risk - a Survey of Institutional Mechanisms. Science Technology \& Human Values 15(2): 226-243.

- Jahn, T., Bergmann, M., \& Keil, F. (2012). Transdisciplinarity: Between mainstreaming and marginalization. Ecological economics, 79, 110. doi:https://doi.org/10.1016/i.ecolecon.2012.04.017

- Krütli, P., Stauffacher, M., Flüeler, T. \& Scholz, R. W. (2010). Functional-dynamic public participation in technological decision-making: site selection processes of nuclear waste repositories. Journal of Risk Research 13(7): 861-875.

- Pohl, C., \& Hirsch Hadorn, G. (2007). Principles for Designing Transdisciplinary Research - proposed by the Swiss Academies of Arts and Sciences (A. Zimmermann, Trans.). München: oekom Verlag.

- Pohl, C., Krütli, P., \& Stauffacher, M. (2017). Ten Reflective Steps for Rendering Research Societally Relevant. GAIA 26(1), 43-51 doi: 10.14512/gaia.26.1.10

- Rowe, G. \& Frewer, L. J. (2005). A Typology of Public Engagement Mechanisms. Science, Technology \& Human Values 30(2): 251-290.

- Sträter, O. (2005) Cognition and safety - An Integrated Approach to Systems Design and Performance Assessment. Ashgate. Aldershot. (ISBN 0754643255)

- Sträter, O., Siebert-Adzic, M. \& Schäfer, E. (2011) Gesundes Führen für effiziente Organisationen der Zukunft. Beitrag für den Herausgeberband Grote, S. (Hrsg.) Die Zukunft der Führung.

- Straeter, O. (2019) Hrsg. Risikofaktor Mensch? - Zuverlässiges Handeln gestalten. Beuth Verlag. 


\section{ETHzürich}

\section{Herzlichen Dank für die Aufmerksamkeit!}

Gefördert durch:

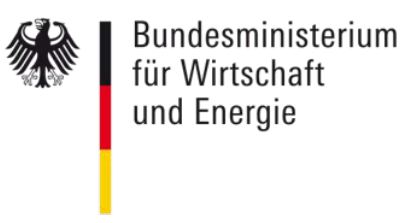

aufgrund eines Beschlusses des Deutschen Bundestages
Gefördert im

Niedersächsischen Vorab der Volkswagenstiftung

$\because 0$.

$\therefore$ : VolkswagenStiftung

$\bullet \bullet$

2. Niedersächsisches Ministerium

für Wissenschaft und Kultur

Förderkennzeichen: 02E11849A-J 